\title{
Suitability Claims under Rule 10b-5: Are Public Entities Sophisticated Enough to Use Derivatives?
}

\author{
Lyle Roberts $\dagger$
}

On December 6, 1994, Orange County, California became the largest municipal bankruptcy in our nation's history. The bankruptcy was the result of derivative transactions made by the county's investment fund that led to over $\$ 2$ billion dollars in estimated losses. ${ }^{1}$ A little over a month later, Orange County filed suit against Merrill Lynch \& Co., contending that the broker breached its fiduciary duty to the county by encouraging it to invest public funds in speculative investments. ${ }^{2}$ The lawsuit stated that in addition to acting as a broker and underwriter of many of the derivatives whose decline in value led to the county's bankruptcy, Merrill Lynch also served as a financial advisor. ${ }^{3}$ Orange County further alleged that the investment firm knew the investment plan it administered was "wholly inappropriate and unsuitable for the County" and that it was aware of "[c]onstitutional and statutory debt and investment limitations applicable to the County." Orange County claimed that any liabilities it incurred in violation of these limitations were "ultra vires and therefore void."

$\dagger$ B.A. 1993, Johns Hopkins University; M.A. 1993, Johns Hopkins School of Advanced International Studies; J.D. Candidate 1996, The University of Chicago.

1 Laura Jereski, Orange County Fund Losses Put At \$2.5 Billion, Wall St J A3 (Dec 12 , 1994). The fund managed $\$ 7.5$ billion for about 180 separate governmental agencies, and was run by Robert L. Citron, the elected Treasurer of Orange County. See G. Bruce Knecht, Derivatives Lead to Huge Loss in Public Fund, Wall St J A3 (Dec 2, 1994).

2 See Orange County Sues Merrill Lynch Over Its Alleged Role in Bankruptcy, 27 Sec Reg \& L Rep (BNA) 131, 131 (Jan 20, 1995).

3 A significant portion of Orange County's investments were in "inverse floaters," a cash flow-based derivative designed to provide a rate of return equal to a fixed rate less a multiple of the floating-rate index, and thus very sensitive to interest rate fluctuations. The numerous increases in short-term interest rates during 1994 had a disastrous effect on these investments. See Derivative Financial Instruments Relating to Banks and Financial Institutions, Hearings Before the Senate Committee on Banking, Housing and Urban Affairs, 104th Cong, 1st Sess 57 (Jan 5, 1995) ("Derivative Financial Instruments Hearings") (statement of Arthur Levitt, Chairman of the SEC).

4 Orange County Sues, 27 Sec Reg \& L Rep (BNA) at 132 (cited in note 2).

5 Id. Merrill Lynch was also a creditor of Orange County because it provided loans 
The past few years have seen at least two other public entities besides Orange County file similar federal "suitability" claims against brokers ${ }^{6}$ over derivative investments. After City Colleges of Chicago experienced "substantial" losses in interestrate-sensitive derivatives, it filed suit against Westcap Government Securities alleging that Westcap made unsuitable investment recommendations. ${ }^{7}$ Additionally, Odessa College, a community college in Odessa, Texas, brought a suitability claim against Grunthal \& Co., arguing that the investment firm had never disclosed that the derivative securities it recommended posed any unusual risks. ${ }^{8}$ Although precedents for these cases are limited, in 1990, San Jose, California recovered millions of dollars of trading losses after pursuing a federal suitability claim against its brokers. ${ }^{9}$ San Jose's success may have encouraged these other public entities to go to court.

The suitability doctrine requires that a broker have a reasonable basis for believing that an investment is appropriate to its customer's financial needs, objectives, and circumstances before it recommends the investment. ${ }^{10}$ Courts have held that the recommendation of unsuitable securities is actionable under Securities and Exchange Commission Rule 10b-5 ("Rule 10b-5") as a specialized fraud claim. ${ }^{11}$ These claims have usually been brought by

as part of "reverse repurchase agreements," which allowed Orange County to raise cash for speculation on the basis of securities it already held. See Jereski, Orange County Fund Losses, Wall St J at A3 (cited in note 1).

- This Comment uses the term "broker" broadly to denote brokers, dealers, and other types of firms engaged in the business of buying and selling securities.

${ }^{7}$ See Community College District No $508 v$ Westcap Gov't Sec, Inc., 1994 US Dist LEXIS 13909, *4-6 (N D IIl).

${ }^{8}$ See G. Bruce Knecht, The Lawyers' Turn: Derivatives Are Going Through Crucial Test, Wall St J A1, A6 (Oct 28, 1994). Other public entities may take part in suitability claims as part of class actions. See Karen Donovan, Derivatives Slump; Losers Go to Court, Nat L J A1 (Nov 7, 1994) (noting that numerous government entities in Minnesota could join class action suit against Piper Jaffray bond fund).

9 See San Jose, Calif., Gets $\$ 18.5$ Million Award in Bond-Losses Suit, Wall St J C13 (June 22, 1990). San Jose settled out of court with eleven defendant brokerages and won a jury verdict against PaineWebber Group, Inc, and E.F. Hutton \& Co. The judgment was later vacated pursuant to a settlement agreement. See text accompanying notes 136-42.

10 The basis of the doctrine is the rules of the New York Stock Exchange ("NYSE") and the National Association of Securities Dealers ("NASD"). See notes 36-37 and accompanying text. See also Robert H. Mundheim, Professional Responsibilities of BrokerDealers: The Suitability Doctrine, 1965 Duke L J 445, 450-51 (analyzing the basis of the suitability doctrine and linking it to the degree of customer reliance on the broker's advice).

1 The discussion of suitability in this Comment is limited to claims brought under the implied right of action for fraud in the purchase or sale of securities found in the Securities Exchange Act of 1934, ch 404, title I, § 10(b), 48 Stat 891, codified at 15 USC $\S$ 
typically unsophisticated investors-including widows, ${ }^{12}$ college students, ${ }^{13}$ and retired school teachers ${ }^{14}$-who have suffered losses in accounts controlled by their brokers.

Although courts have been reluctant to recognize suitability claims brought by sophisticated investors,${ }^{15}$ the complex nature of derivatives has prompted calls for expanding the suitability doctrine to protect institutional investors who do not understand the risks of their investments. ${ }^{16}$ Currently, the various elements demanded by courts for suitability claims could be extended to cover a public entity, regardless of whether the public entity actively sought a high rate of return or had other particular financial needs that led it to the derivatives market. ${ }^{17}$

78j(b) (1994), and Rule 10b-5, 17 CFR $\S 240.10 \mathrm{~b}-5$ (1995), promulgated thereunder. See, for example, Clark v John Lamula Investors, Inc., 583 F2d 594, 600-01 (2d Cir 1978) (allowing a cause of action for fraud under Rule 10b-5). Rule 10b-5 provides:

It shall be unlawful for any person, directly or indirectly, by use of any means or instrumentality of interstate commerce, or of the mails or of any facility of any national securities exchange,

(a) To employ any device, scheme, or artifice to defraud,

(b) To make any untrue statement of material fact or to omit to state a material fact necessary in order to make the statements made, in the light of the circumstances under which they were made, not misleading, or

(c) To engage in any act, practice, or course of business which operates or would operate as a fraud or deceit upon any person,

in connection with the purchase or sale of any security.

See note 33 for a fuller discussion of the Rule $10 \mathrm{~b}-5$ basis for particular suitability claims.

${ }_{12}$ Hecht $v$ Harris, Upham \& Co., 430 F2d 1202, 1206 (9th Cir 1970).

${ }^{13}$ Clark v Kidder, Peabody \& Co., 636 F Supp 195, 196 (S D NY 1986).

14 Clark v John Lamula Investors, 583 F2d at 597.

15 For example, in Bull $v$ Chandler, a case involving an Apple Computer engineer who signed documents indicating a sufficient level of experience and sophistication, the court emphatically declared that "[t]he federal securities laws are not an insurance policy for investors who trust their financial well-being to salespersons who have no legal duty to look out for their best interests." [1991-92 Transfer Binder] Fed Sec L Rep (CCH) I 96,567 at 92,622 (N D Cal 1992).

${ }_{16}$ See, for example, Peter Blackman, Dealing in Derivatives, NY L J 5 (May 12, 1994) ("[E]ven some large institutions act like babes in the woods when it comes to negotiating derivatives contracts."); Stuart D. Root, Suitability: The Sophisticated Investor-And Modern Portfolio Management, 1991 Colum Bus L Rev 287, 355 (noting that in the context of rapidly evolving investment opportunities, "[i]nvestor sophistication, as that term is generally used, may in fact be a myth").

17 As of mid-1995, San Jose, California, was the only public entity to obtain a favorable verdict under the suitability doctrine. However, the apparent dearth of successful claims by public entities may be a function of the prevalence of settlements and binding arbitration agreements in these types of suits. See, for example, Community College District, 1994 US Dist LEXIS 13909, *22 (granting defendants' motion to compel arbitration). 
A public entity seeking to recover derivative losses from its broker would likely claim that the complexity of derivative investments left it unable to evaluate properly its broker's recommendations and that it thus ceded effective control over its account to the broker. In some cases, as in the Orange County example, the public entity might also argue that the broker had a responsibility to determine whether the public entity was exceeding its legal authority by engaging in high-risk trading. Thus, the question with which courts will have to grapple is whether a public entity trading in derivatives should be able to claim that it is an unsophisticated investor for purposes of those transactions.

This Comment addresses various approaches to suitability claims under Rule 10b-5 and argues that courts should hold that public entities sustaining losses in derivatives are not, despite the complexity of those instruments, capable of stating a suitability claim. Section I provides a functional definition of derivatives and briefly surveys the applicability of federal securities law to derivative transactions. Section II looks at the development of the suitability doctrine and how courts have addressed suitability claims under Rule 10b-5. Sections III and IV analyze the role of investor sophistication in suitability claims and examine how suitability claims brought by public entities in other contexts may effect claims involving derivatives. Section V considers whether the suitability doctrine should be applied to derivative investments by public entities, and argues that this would be an unnecessary judicial innovation. This Comment ultimately concludes that Rule $10 \mathrm{~b}-5$ should not be construed to support suitability claims by public entities against their brokers.

\section{THE REgULATION OF DERIVATIVES}

\section{A. A Functional Definition of Derivatives}

The threshold determination for any suitability claim involving derivatives is the nature of the investment involved, ${ }^{18}$ because only financial instruments defined under federal law as "securities" fall within the scope of Rule $10 \mathrm{~b}-5 .{ }^{19}$ In the most

${ }^{18}$ See, for example, Joanne Medero, Michael B. Carlinsky, and Elizabeth P. Hensley, Investing in Derivatives: Current Litigation Issues, 8 Insights 4, 6 (Nov 1994) (Derivative suitability turns on the nature of the instrument that is the subject of the transaction.).

19 The definitions of a "security" for purposes of SEC regulations are found in the Securities Act of 1933, 15 USC $\S 77 b(1)$ (1994), and the Securities and Exchange Act of 1934, 15 USC $\S 78 \mathfrak{c}(a)(10)$ (1994). Each definition includes: 
basic sense, a derivative is simply a contract that either allows or obligates one of the parties to buy or sell an asset. Because movements in the value of the underlying asset affect the value of the contract, the value of the contract is "derived" from the value of the underlying asset. There are essentially two types of derivatives: "market-based derivatives," the value of which is based on the market value of an underlying security or interest, and "cash flow-based derivatives," whose value is based on subdividing the rights to cash flow on an instrument, for example, interest payments on a debt security. Market-based derivatives can include options, swaps, futures, and forwards. Cash flow-based derivatives are primarily based on debt instruments, such as mortgagebacked securities. ${ }^{20}$

Although many derivatives are traded on organized exchanges, ${ }^{21}$ institutional investors often negotiate derivative transactions directly with financial institutions. These direct transactions make up the "over-the-counter" or "OTC" derivatives market. $^{22}$ OTC derivatives can serve four main financial functions: asset/liability management, creation of synthetic assets or liabilities, hedging, and speculation. ${ }^{23}$ For public entities, speculation has become increasingly tempting as they search for increased returns or reduced borrowing costs in times of tight budgets. ${ }^{24}$

[A]ny note, ... bond, debenture, ... put, call, straddle, option, or privilege on any security, certificate of deposit, or group or index of securities (including any interest therein or based on the value thereof), or any put, call, straddle, option, or privilege entered into on a national securities exchange relating to foreign currency.

15 USC $\S 77 \mathrm{~b}(1) ; 15$ USC $\S 78 \mathrm{c}(a)(10)$. For a discussion of how this statutory language has been applied in the courts, see generally Park McGinty, What is a Security?, 1993 Wis L Rev 1033.

20 For a general discussion of various types of derivatives, see Roger D. Blanc, Developing Internal Controls to Manage Derivatives, 9 Insights 7, 7 (Apr 1995).

21 Stock options and commodity futures are common examples of such derivatives. Prominent exchanges dealing in these investments include the Chicago Mercantile Exchange, the New York Mercantile Exchange, and the Chicago Board Options Exchange.

${ }_{22}$ For a more complete discussion of the OTC derivatives market, see generally Henry T.C. Hu, Misunderstood Derivatives: The Causes of Informational Failure and the Promise of Regulatory Incrementalism, 102 Yale L J 1457 (1993); Geoffrey B. Goldman, Note, Crafting a Suitability Requirement for the Sale of Over-The-Counter Derivatives: Should Regulators "Punish the Wall Street Hounds of Greed"?, 95 Colum L Rev 1112 (1995).

${ }^{23}$ For a description of these uses, see generally Daniel P. Cunningham, et al, An Introduction to OTC Derivatives, 892 PLI/Corp 113, 125-27 (1995).

${ }^{24}$ Derivative Financial Instruments Hearings (Jan 6, 1995) at 223 (cited in note 3) (statement of Bonnie Ridley Kraft, President of the Government Finance Officers Association) ("The pressure for increased returns or reduced borrowing costs in times of tight budgets is a significant factor affecting decisions to use particular instruments."). 
Public entities often choose to speculate using derivatives based on debt securities that are issued by government-sponsored entities. ${ }^{25}$ While the credit risk of these derivatives is minimal, ${ }^{26}$ the market risk can be considerable depending on how sensitive the instrument is to changes in interest rates. ${ }^{27}$ In some instances, movements in interest rates can have devastating effects on the ability of public entities and other investors to maintain their market positions. ${ }^{28}$

\section{B. The Jurisdictional Basis for Suitability Claims over Derivatives under Federal Securities Law}

Fraud claims arising from derivative transactions can be brought under the regulatory authority of either the Securities and Exchange Commission ("SEC") or the Commodities Futures Trading Commission ("CFTC"), depending on how the transactions are characterized. ${ }^{29}$ The jurisdiction of the SEC, and therefore the applicability of Rule $10 \mathrm{~b}-5$, extends to transactions in-

25 Examples include debt securities issued by the Federal Home Loan Bank System and the Federal National Mortgage Association. See Randall Smith, Should Agencies Share Blame For Peddling Risk?, Wall St J C1 (Dec 12, 1994).

${ }^{26}$ Id at $\mathrm{C} 17$.

${ }^{27}$ Id at $\mathrm{C} 1$. Losses can also be magnified by leveraging through the use of devices such as reverse repurchase agreements. See note 5 .

${ }^{28}$ The preeminent example, of course, is Orange County, which found itself forced to declare bankruptcy after creditors demanded that it put up more cash to guarantee its loans following declines in the values of its collateral securities. See Daniel B. Wood, County Gropes for Way Out of Woods, Christian Sci Monitor 4 (May 5, 1995).

29 In 1983, Congress codified a jurisdictional accord between the SEC and the CFTC regarding the classification of certain derivative financial instruments. Futures Trading Act of 1982, $\S 101$, Pub L No 97-444, 96 Stat 2294, 2294-96, codified at 7 USC $\S \S 2,2 a$ (1994). See also Thomas A. Russo, Regulation of Equity Derivatives, 848 PLI/Corp 595, 607-08 (1994) (discussing the split jurisdictional relationship between the SEC and the CFTC). As a result, the CFTC has exclusive jurisdiction over all futures contracts, options on futures contracts and options on physical commodities. Id at 608. The SEC, on the other hand, has exclusive jurisdiction over options directly on securities (including options on government and exempted securities), certificates of deposit, and stock indices. Id; 7 USC $\S 2 \mathrm{a}(\mathrm{i})$. For example, a bond issued by a corporation is a security, as is an option to purchase the bond. See Daniel P. Cunningham, et al, SEC/CFTC Administrative Proceedings Against BT Securities Corporation, 892 PLI/Corp 391, 398 (1995).

The nature of many OTC derivatives, however, makes it difficult to describe them as either "securities" or "futures contracts," and this difficulty creates uncertainty over applicable laws. Judge Easterbrook has described the problem as analogous to "whether tetrahedrons belong in square or round holes." Chicago Mercantile Exchange $v$ SEC, 883 F2d 537, 539 (7th Cir 1989). In Chicago Mercantile Exchange, for example, the court held that although index participations had characteristics of both futures contracts and securities, as futures contracts they were subject to the exclusive jurisdiction of the CFTC. Id at 548 . 
volving "securities" as defined by federal law. ${ }^{30}$ Although significant questions still remain concerning the characterization and regulation of some OTC derivatives, ${ }^{31}$ derivatives based directly on securities fall within the jurisdiction of the SEC. ${ }^{32}$ Furthermore, the SEC has recently demonstrated a willingness to extend its jurisdiction to derivatives that are not based directly on securities, but that are related to the prices or yields of securities, potentially expanding the applicability of Rule $10 \mathrm{~b}-5 .^{33}$ In any

\section{See note 19.}

31 Public entities have a strong incentive to bring suitability claims under Rule 10b-5 rather than the similar antifraud provisions of the Commodity Exchange Act of 1936 ("CEA"), 7 USC $\S 6 b$ (1994). Specifically, the CFTC has been less willing than the SEC to recognize a "suitability doctrine" for investments within its jurisdiction. See Root, 1991 Colum Bus L Rev at 320 \& n 94 (cited in note 16). A former CFTC Commissioner has publicly criticized the CFTC for making it "too hard for investors to recover for losses arising from misconduct by commodities professionals." Angela Drolte and Suzanne Elam Manning, Schapiro Says CFTC's Door Is Open to Industry, But Agency Won't Be Bullied', 26 Sec Reg \& L Rep (BNA) 1624, 1628 (1994) (quoting former Commissioner Fowler West). Instead, the CFTC has required brokers only to furnish their customers with written disclosures of the risks of futures trading, placing the responsibility on customers to determine their own suitability levels. See Commodity Futures Trading Commission, Distribution of Risk Disclosure Statement, 17 CFR $\S \S 1.55,32.5,33.7$ (1995). Although the CFTC and courts have recognized claims when a broker fraudulently misrepresents the risks of trades, see, for example, Clayton Brokerage Co. v Commodity Futures Trading Comm'n, 794 F2d 573, 578 (11th Cir 1986) (upholding CFTC decision under \& 4b of the CEA), those institutions have refused to recognize suitability claims alleging that a broker failed to convey the risky nature of a trade, especially when such claims are brought by sophisticated customers. See, for example, Puckett $v$ Rufenacht, Bromagen \& Hertz, Inc., 903 F2d 1014, 1018-19 (5th Cir 1990) (holding that broker had adequately conveyed the risks of commodities futures to plaintiff, an educated investor who had thirty years experience trading securities). Overall, the possible suitability claims for a public entity under the CEA are more limited than those available under the federal securities laws.

${ }^{32}$ These include different variations of structured securities and deposits, stripped securities, and securities with option characteristics. See Cunningham, et al, 892 PLI/Corp at 119 (cited in note 23).

${ }^{33}$ See In re BT Securities Corp, 1994 SEC LEXIS 4041; In re BT Securities Corp, 1994 CFTC LEXIS 340. In BT Securities, the SEC and the CFTC issued joint orders imposing remedial sanctions against BT Securities in connection with its derivative transactions with Gibson Greetings, Inc. In holding that Rule 10b-5 applied to the transactions at issue, the SEC pointed to two different transactions, which it characterized as cash-settled put and call options based on government securities. Neither transaction involved a direct option on government securities; rather, both involved a series of payments linked to yields or prices of certain U.S. Treasury securities. BT Securities, 1994 SEC LEXIS 4041, *10. See also Cunningham, et al, 892 PLI/Corp at 399 (cited in note 29) (discussing the SEC's classification of these financial instruments as securities). Although it offers some guidance on the SEC's view of the reach of Rule 10b-5 in the context of derivatives, $B T$ Securities has a limited effect because the SEC did not explain the reasoning behind its analysis, and courts need not defer to the SEC's decision. See G. Bruce Knecht, P\&G Amends Lawsuit Naming Bankers Trust, Wall St J A3, A14 (Feb 7, 1995) (stating that without the SEC opinion, a plaintiff would have to convince a judge to "break new ground" to determine that these types of derivatives could be regulated under federal securities laws). 
event, the nature of any public entity's derivatives portfolio-and, thus, the applicability of Rule 10b-5 - can only be determined on a case-by-case basis. Moreover, while some public entities may invest in derivative instruments outside the jurisdiction of the SEC, recent losses have primarily occurred in derivatives based on government securities. ${ }^{34}$ These types of derivatives are accepted as securities for legal purposes and, therefore, can give rise to claims of Rule $10 \mathrm{~b}-5$ violations. ${ }^{35}$

\section{SUITABILITY Claims UNDER RULe 10B-5}

The suitability doctrine is premised on the New York Stock Exchange's "Know Your Customer Rule"36 and the National Association of Securities Dealers Rules of Fair Practice. ${ }^{37}$ These rules were promulgated within the statutory context of $\S 15 \mathrm{~A}$ of the Securities Exchange Act of $1934 .^{38}$ Section 15A governs the

34 See text accompanying notes 25-28. City Colleges of Chicago, for example, experienced losses trading in "two varieties of highly interest-rate-sensitive collateralized mortgage obligations ('CMOs') known as 'principal-onlys' ('POs') and support class principalonlys ('SPOs')" issued by the Federal National Mortgage Association. Community College District No $508 v$ Westcap Gov't Sec, Inc., 1994 US Dist LEXIS 13909, *3-4 (N D III). Similarly, the President of Odessa College, in testimony before Congress, claimed that his institution's losses came about through investments in "collateralized mortgage obligations directly issued by a federal agency." Hearings on Recent Derivative Losses before the Fouse Committee on Banking, Finance and Urban Affairs, 103d Cong, 2d Sess 90, 91 (1994) ("Recent Derivative Losses Hearings") (statement of Philip Speegle, President of Odessa College).

${ }^{35}$ In Shearson/American Express, Inc. $v$ McMahon, the Supreme Court held that Rule 10b-5 claims can be subject to binding arbitration agreements between brokers and their clients. 482 US 220,238 (1987). This has led some commentators to conclude that suitability actions may become rare. See, for example, Goldman, Note, 95 Colum L Rev at 1133 (cited in note 22). However, although the suitability claim of City Colleges of Chicago was dismissed on this basis, see Community College District, 1994 US Dist LEXIS $13909, * 22-24$, public entities continue to file enough suits under Rule 10b-5 to belie any speculation that the suitability doctrine has been privately contracted out of existence. See text accompanying notes 7-9.

${ }_{36}$ NYSE Rule 405(1) provides in part: "Every member organization is required . . . to (1) Use due diligence to learn the essential facts relative to every customer, every order, every cash or margin account accepted or carried by such organization." 2 NYSE Guide (CCH) Il 2405 at 3696 (1994).

37 NASD Rules of Fair Practice, Article III, Section 2(a) provides:

In recommending to a customer the purchase, sale or exchange of any security, a member shall have reasonable grounds for believing that the recommendation is suitable for such customer upon the basis of the facts, if any, disclosed by such customer as to his other security holdings and as to his financial situation and needs.

${ }^{38} 48$ Stat 881 , codified at 15 USC $\$ \S 78$ a et seq (1994). 
registration of national securities associations and requires the SEC to determine that the "rules of the association are designed to prevent fraudulent and manipulative acts and practices." ${ }^{\prime 39}$ Most courts, however, have rejected claims that these rules create private causes of action, citing the absence of a congressional intent to do so. ${ }^{40}$ Instead, courts have simply held that actions that violate the NYSE or NASD rules can also constitute violations of Rule 10b-5. ${ }^{41}$ Once courts determined that suitability claims were independently supported by Rule 10b-5, such claims could be brought over any transaction regulated by the SEC. For example, even though the trading of government securities does not fall under the jurisdiction of the NYSE or the NASD, their sale and purchase are still covered by the antifraud provisions of the securities laws. As a result, investors may bring suitability claims involving government securities under Rule $10 \mathrm{~b}-5 .{ }^{42}$

In establishing the various elements of suitability claims, courts have frequently analogized to churning cases. ${ }^{43}$ Churning occurs when a broker trades excessively in a discretionary account. Both suitability and churning claims are implied actions for fraud under Rule $10 \mathrm{~b}-5,44$ and both fit within the spirit of the securities laws. Lacking direct statutory text or Supreme Court precedent, however, both claims have been subject to judicial development. Moreover, there are important differences between churning and suitability. As one commentator has noted, al-

3915 USC $\S 780-3(b)(6)$.

40 See, for example, Jablon v Dean Witter \& Co., 614 F2d 677, 679-81 (9th Cir 1980) (denying a private right of action for violation of the NYSE and NASD rules); Picard $v$ Wall Street Discount Corp, 526 F Supp 1248, 1250-51 (S D NY 1981) (agreeing with Jablon court that Congress did not intend a private cause of action for violations of the NYSE rules); Pierson v Dean, Witter, Reynolds, Inc., 551 F Supp 497, 501 (C D Ill 1982) (finding no congressional intent to imply a private right of action under several sections of the Securities Exchange Act of 1934).

41 See, for example, O'Connor v R.F. Lafferty \& Co., 965 F2d 893, 897 (10th Cir 1992) (failing to decide whether a violation of the NASD Rules gives rise to a private cause of action because activities that violate the NASD Rules may also violate Rule 10b-5).

42 See, for example, Frota v Prudential-Bache Securities, Inc., [1987 Transfer Binder] Fed Sec L Rep (CCH) II 93,253 at 96,220 (S D NY) (allowing suitability claim involving government bonds and rejecting argument that government securities are exempted from NASD rules).

${ }^{43}$ See, for example, O'Connor, 965 F2d at 898 (commenting on relationship between churning and suitability); City of San Jose $v$ Paine, Webber, Jackson \& Curtis, Inc., 1991 US Dist LEXIS 8318, * 6-7 ( $\mathrm{N} \mathrm{D} \mathrm{Cal)} \mathrm{(order} \mathrm{memo)} \mathrm{(analyzing} \mathrm{the} \mathrm{relationship} \mathrm{between}$ churning and suitability). For a discussion of the relationship between suitability and churning, see generally Mark C. Jensen, Abuse of Discretion Claims Under Rule 10b-5: Churning, Unsuitability, and Unauthorized Transactions, 18 Sec Reg L J 374 (1991).

14 See notes 11 and 70 for discussion of implied actions for fraud under Rule 10b-5. 
though churning has "a well-defined set of elements and a substantial body of interpretive case law[,] ... the law of unsuitability is so scattered that the cause of action is difficult to define.".45 Suitability has been applied in two distinct types of claims: (1) claims based on a misrepresentation or omission (specialized versions of ordinary misrepresentation or omission claims); and (2) claims based on fraudulent practice (closely resembling churning claims). Because courts frequently use other Rule 10b-5 cases as precedent in analyzing suitability claims, this Comment also draws on ordinary misrepresentation, omission, and churning cases to inform its discussion of suitability.

\section{A. Suitability Claims Based on Omission or Misrepresentation}

The majority of suitability claims are brought under a "misrepresentation" or "omission" theory. ${ }^{46}$ Under these theories, an investor can establish liability by demonstrating that the broker did not accurately convey the risks of the purchased securities ${ }^{47}$ or recommended a course of trading that was at odds with the investor's stated objectives. ${ }^{48}$ The elements of this type of suitability claim are well established. The investor must prove that: (1) the broker knew or reasonably believed that the securities purchased were unsuitable given the investor's objectives; (2) the broker, with scienter, made material misrepresentations (or, owing a duty to the investor, failed to disclose material information) relating to the suitability of the investments; and (3) the investor justifiably relied, to its detriment, on the broker's fraudulent conduct. ${ }^{49}$

\section{Element of scienter.}

The requirement of scienter, or acting with the knowing intent to deceive, manipulate, or defraud, stems from the Su-

45 Jensen, 18 Sec Reg L J at 375 (cited in note 43).

46 Id at 384.

47 See, for example, Clark $v$ John Lamula Investors, Inc., 583 F2d 594, 597-98 (2d Cir 1978) (holding broker liable for failing to explain to the plaintiff-schoolteacher that she was buying speculative securities involving great financial risk).

48 See, for example, Cruse v Equitable Securities of New York, Inc., 678 F Supp 1023, 1031-32 (S D NY 1987) (sustaining a suitability claim where broker cashed in investor's blue-chip stocks to purchase unauthorized, risky call options).

49 See Brown v E.F. Hutton Group, Inc., 991 F2d 1020, 1031 (2d Cir 1993) (discussing elements of suitability claims based on misrepresentation or omission); O'Connor $v$ R.F. Lafferty \& Co., 965 F2d 893, 897 (10th Cir 1992) (same). 
preme Court's decision in Ernst \& Ernst $v$ Hochfelder. ${ }^{50}$ In that case, the Court held that fraud actions brought under Rule 10b-5 must allege scienter on the part of the defendant, but it left open the question of whether reckless conduct could amount to scienter. ${ }^{51}$ A majority of the circuit courts of appeals, however, has since adopted a recklessness standard for scienter in Rule 10b-5 claims. ${ }^{52}$ For most courts applying this standard, scienter has hinged on the factual question of the unsuitability of the recommended securities. Where an investor has established that the securities in question were too risky considering the investor's objectives, courts have found scienter based either on the broker's affirmative recommendation of the unsuitable securities ${ }^{53}$ or, in the presence of a fiduciary duty, on the broker's failure to inform the investor of the risks involved. ${ }^{54}$

\section{Element of duty to disclose for omission claims.}

Along with the normal requirements of a suitability claim, a claim based on an omission must also allege that the broker had a "duty to disclose" the risks of the investor's purchases. This duty is necessary to bring suitability claims based on omission under the more general requirement of Chiarella $v$ United States, in which the Supreme Court held that liability for fraud based on omission under Rule 10b-5 "is premised upon a duty to disclose arising from a relationship of trust and confidence. ${ }^{155}$ The Court clarified this requirement in Dirks $v S E C$, in which it held that the duty to disclose arises from the existence of a fiduciary rela-

so 425 US 185, 193 (1976).

51 Id at 193-94 n 12.

52 See Van Dyke v Coburn Enterprises, Inc., 873 F2d 1094, 1100 (8th Cir 1989) (noting that Second, Third, Fifth, Seventh, Ninth, Eleventh and D.C. Circuits had adopted a recklessness standard and doing so itself). See also Sundstrand Corp v Sun Chemical Corp, 553 F2d 1033, 1044-45 (7th Cir 1977) (relying on common law fraud analogy to support adoption of a recklessness standard). For a more complete discussion of the development of the recklessness standard, see Root, 1991 Colum Bus L Rev at 316-19 (cited in note 16).

${ }_{53}$ See, for example, Boettcher \& Company, Inc. $v$ Munson, 854 P2d 199, 209-10 (Colo 1993) (analyzing state claim similar to Rule 10b-5 claim and holding that a broker's recommendation of risky limited partnership shares was unsuitable).

54 See, for example, Vucinich $v$ Paine, Webber, Jackson \& Curtis, Inc., 803 F2d 454, 460 (9th Cir 1986) (holding that broker failed to fulfill his duty of explaining the risky nature of short selling); Clark v John Lamula Investors, Inc., 583 F2d 594, 598 (2d Cir 1978) (Broker failed to explain the risk of highly speculative securities.). See also text accompanying notes $65-68$.

5s 445 US 222, 230 (1980). 
tionship. ${ }^{56}$ In thus requiring a fiduciary relationship as a prerequisite to liability for omissions, the Court noted that not to require this relationship "would amount to 'recognizing a general duty between all participants in market transactions." "'57 For good reason, the Court was unwilling to go so far.

\section{Element of justifiable reliance.}

A plaintiff's burden regarding the reliance element of a Rule 10b-5 claim varies depending on whether the claim alleges false statements or material omissions. ${ }^{58}$ In the case of a misrepresentation, justifiable reliance establishes a causal connection between the fraudulent act and the investor's harm. To make this link, the investor must demonstrate that he or she relied on the misrepresentation when entering into the disputed transaction. ${ }^{59}$ Courts have used different factors to evaluate reliance, including the investor's experience and sophistication, the duration of the relationship between the parties, the presence of a fiduciary relationship, and the specificity of the misrepresentation. ${ }^{60}$ The wide array of possibly relevant factors has made determinations of justifiable reliance extremely fact specific. In the aggregate, however, an investor's level of sophistication has been the most important factor in determining whether reliance was justified. ${ }^{61}$

In contrast to its analogue in a misrepresentation claim, the justifiable reliance element of an omission claim involves a significantly reduced burden of proof. In Affiliated Ute Citizens of Utah $v$ United States, the Supreme Court held that "positive proof of reliance is not a prerequisite to recovery" where a Rule $10 \mathrm{~b}-5$ claim is premised on an omission. "All that is necessary is that the facts withheld be material in the sense that a reasonable investor might have considered them important in the making of [a] decision." ${ }^{\text {63 }}$ Thus, omission in itself is sufficient to

56463 US 646, 654-55 (1983).

57 Id at 655, quoting Chiarella, 445 US at 232-33.

ss See Burke v Jacoby, 981 F2d 1372, 1378-79 (2d Cir 1992) (differentiating between a false statements claim and a material omissions claim).

59 Id.

60 See Bull v Chandler, [1991-92 Transfer Binder] Fed Sec L Rep (CCH) II 96,567 at 92,621 (N D Cal 1992) (listing factors drawn from cases involving misrepresentations in the sale of limited partnership shares).

${ }_{61}$ For a more complete discussion of sophistication and justifiable reliance, see generally Root, 1991 Colum Bus L Rev 287 (cited in note 16). See also Section III.B.2.

62406 US 128, 153-54 (1972).

$\Leftrightarrow$ Id. 
demonstrate causation. Once the plaintiff shows an omission, the burden shifts to the broker to prove that the investor would have made the same investment if all the material facts had been disclosed. ${ }^{64}$

4. Adjudication of a suitability claim based on misrepresentation or omission.

In cases involving unsophisticated investors, adjudicating a suitability claim based on a misrepresentation or omission can be fairly straightforward. For example, in Vucinich $v$ Paine, Webber, Jackson \& Curtis, Inc., a housewife brought a suitability claim against her broker based on an omission theory. ${ }^{65}$ Vucinich initially told the broker she was not interested in high-risk investments. Despite Vucinich's investment objectives and her limited knowledge of financial markets, however, the broker recommended short selling and failed to explain its inherent risks. ${ }^{66}$

Under these circumstances, the Ninth Circuit held that the broker "had a duty to explain the nature of short selling to Vucinich in a way that she could understand what she was getting into. Failure to perform that duty would amount to reckless violation of Section 10(b) of the Securities Exchange Act.".67 Thus, Vucinich followed a clear pattern: the broker knew that the securities were unsuitable; the broker neglected its duty to disclose; and the broker's omission was sufficient to demonstrate causation. It should be noted, however, that the plaintiff's lack of sophistication was a key factor in the court's determination that she was owed a duty by her broker. Similarly, in a suitability claim based on misrepresentation, a plaintiff's lack of sophistication would greatly contribute to a court's finding of justifiable reliance. ${ }^{68}$

\section{B. Suitability Claims Based on Fraudulent Practice}

Recently, courts have begun to differentiate suitability claims based on misrepresentation and omission and suitability claims brought under a "fraudulent practice" theory, where the plaintiff asserts fraud by conduct. ${ }^{69}$ Under the fraudulent practice theo-

64 duPont $v$ Brady, 828 F2d 75, 78 (2d Cir 1987).

is 803 F2d 454, 456-57 (9th Cir 1986).

66 Id.

${ }^{67}$ Id at 460 .

${ }^{68}$ See Section III for a fuller discussion of this point.

69 See, for example, City of San Jose v Paine, Webber, Jackson \& Curtis, Inc., 1991 
ry, the knowing recommendation of unsuitable trading is itself actionable. ${ }^{70}$ Therefore, investors need not prove the existence of fraudulent misrepresentations or omissions. ${ }^{71}$ In analyzing fraudulent practice suitability claims, at least one court has required the same elements found in cases involving claims of churning. ${ }^{72}$ The investor must prove that: (1) the broker recommended (or, in the case of a discretionary account, purchased) securities that were unsuitable considering the investor's objectives; (2) the broker purchased or recommended the securities with scienter; and (3) the broker exercised control over the investor's account. ${ }^{73}$ While the unsuitability and scienter requirements mirror the elements of a suitability claim based on misrepresentation or omission, the control element is unique to suitability claims based on fraudulent practice.

\section{Element of control.}

Cases involving fraudulent practice suitability claims have frequently included claims of churning, making it difficult to separate the two lines of analysis. ${ }^{74}$ This is especially true in cases that have required the element of control only for the churning claim. ${ }^{75}$ Recognizing the congruity between the two

US Dist LEXIS 8318, *1 (N D Cal) (order memo); O'Connor v R.F. Lafferty \& Co., 965 F2d 893, 897 (10th Cir 1992), citing City of San Jose, 1991 US Dist LEXIS 8318, *1. See generally Jensen, $18 \mathrm{Sec}$ Reg L J at 384-90 (cited in note 43).

${ }^{70}$ See City of San Jose, 1991 US Dist LEXIS $8318, * 5$ (Knowing recommendation of unsuitable trading instrument is fraud by conduct.); O'Connor, $965 \mathrm{~F} 2 \mathrm{~d}$ at 898 (same). The essential difference between suitability claims based on misrepresentation or omission and suitability claims based on fraudulent practice is the particular section of Rule 10b-5 on which the plaintiff bases the claim. Rule 10b-5(a) and Rule 10b-5(c) address fraudulent "practices" and "acts"; Rule 10b-5(b) addresses fraudulent "representations" and "omissions." See note 11.

7 City of San Jose, 1991 US Dist LEXIS $8318, * 5$.

72 O'Connor, 965 F2d at 898. See also City of San Jose, 1991 US Dist LEXIS 8318, *57 (analyzing the similarity between churning and suitability claims).

${ }^{23}$ O'Connor, 965 F2d at 898.

74 See, for example, Mihara $v$ Dean Witter \& Co., Inc., 619 F2d 814, 817 (9th Cir 1980) (conflating churning and suitability claims). In at least one case, the plaintiff used the unsuitability of the investments as support for the control element of a churning claim. Memphis Housing Authority v Paine, Webber, Jackson \& Curtis, Inc., 639 F Supp 108,115 (W D Tenn 1986) (" $[\mathrm{H}]$ ad plaintiff been apprised of the risks associated with Davis' investments it would have engaged in another course of investment that would have involved less trading."). See also Jensen, 18 Sec Reg L J at 386-87 (cited in note 43) (noting tendency of courts to treat unsuitability claims as "analogous to or part of the churning claims that almost inevitably accompany them").

${ }^{75}$ See, for example, Cruse $v$ Equitable Securities of New York, Inc., 678 F Supp 1023, 1030-32 (S D NY 1987) (noting that broker handled plaintiff's account as if he had full discretionary authority, but discussing necessity of control only in connection with churn- 
types of claims, at least one recent court decision has required the identical elements for both claims. In O'Connor $v$ R.F. Lafferty \& Co., the Tenth Circuit discussed the relationship between the two:

[C]hurning deals with the quantity of securities purchased for an account, while unsuitability concerns the quality of the purchased securities. Federal courts have used the NYSE and NASD rules to analyze both forms of broker misconduct. Thus we will examine the elements of a churning claim to aid our analysis of unsuitability elements. ${ }^{76}$

Noting that "[w]hether the control element of a churning claim applies to its cousin the unsuitability claim has been an open question," the O'Connor court eventually concluded that this element was essential to satisfy the causation/reliance requirement of a Rule $10 \mathrm{~b}-5$ violation. ${ }^{77}$

The argument in favor of requiring a control element for fraudulent practice suitability claims stems from the relationship between the two different kinds of suitability claims. A control element would serve the same function-establishing causation-as the justifiable reliance element of misrepresentation or omission suitability claims. Without the control element, a broker would be liable under Rule 10b-5, on a fraudulent practice theory, for merely trading in unsuitable securities. Under this approach, an investor could bring a suitability claim even after conceding that he approved the transactions knowing the risks involved. One court has suggested that such a result simply would lead plaintiffs to consistently abandon churning claims for suitability claims. ${ }^{78}$

Courts requiring the element of control often look to churning cases to provide interpretive law. ${ }^{79}$ In Mihara $v$ Dean Witter $\&$ Co., the Ninth Circuit held that control is established either by the broker's discretionary authority to buy and sell securities on

ing claim).

${ }^{76} 965$ F2d 893, 898 (10th Cir 1992).

77 Id.

${ }_{78}$ See City of San Jose v Paine, Webber, Jackson \& Curtis, Inc., 1991 US Dist LEXIS $8318, * 7$ (N D Cal) (order memo).

79 See, for example, Wieringa v Oppenheimer \& Co., [1984-85 Transfer Binder] Fed Sec L Rep (CCH) II 91,986 at 90,906 (N D Ohio 1985), citing a churning case, Follansbee $v$ Davis, Skaggs \& Co., 681 F2d 673, 677 (9th Cir 1982), in support of its control determination. For an overview of the control element in churning cases, see generally Patricia $A$. O'Hara, The Elusive Concept of Control in Churning Claims Under Federal Securities and Commodities Law, 75 Georgetown L J 1875 (1987). 
behalf of the investor or by a finding that the investor routinely followed the dealer's recommendations. ${ }^{80}$ More recent churning cases, however, have declared the Mihara definition of control an oversimplification. In Follansbee $v$ Davis, Skaggs \& Co., a case involving both churning and suitability claims, the court concluded that control "simply cannot be construed to mean that the most sophisticated investor is not in control of his account simply because he usually follows the recommendations of his broker." Follansbee had a college degree in economics, read and understood corporate reports, and was a regular reader of investment literature. The court concluded that "Follansbee's acceptances of [the broker's] recommendations were not the passive acquiescence of an uninformed dependent."

In addition to investor sophistication, courts also examine how trading decisions are made to determine whether the broker exercised constructive control over an account. ${ }^{83}$ In suitability cases, this evaluation has meant that even if an investor acquiesces to the broker's recommendations, he retains control of his account if he has sufficient financial acumen to understand the risks of his investments and maintains an active role in monitoring his account. ${ }^{84}$

2. Adjudication of a suitability claim based on fraudulent practice.

Once a court determines that the broker had control over the account, the adjudication of a fraudulent practice suitability claim mirrors the adjudication of a suitability claim based on misrepresentation. In Clark $v$ Kidder, Peabody \& Co., the broker controlled a discretionary account for a college student who informed the broker that he desired a fixed income from his investments. ${ }^{85}$ The court held that the broker's act of purchasing speculative, high-tech stocks was sufficient to support a claim of unsuitability. ${ }^{86}$ In other words, the broker purchased unsuitable

so 619 F2d 814, 821 (9th Cir 1980).

s1 681 F2d 673, 677 (9th Cir 1982).

82 Id at 678

83 See Tiernan v Blyth, Eastman, Dillon \& Co., 719 F2d 1, 3-4 (1st Cir 1983) ("[E]ven a sophisticated investor who blindly relinquishes all decisions to a broker may not be in control of his account.").

${ }^{84}$ See Wieringa, [1984-85 Transfer Binder] Fed Sec L Rep (CCH) II 91,986 at 90,906 (finding plaintiff retained control over his account because he understood options trading and had the capacity to approve or disapprove the trades).

ss 636 F Supp 195, 196 (S D NY 1986).

s6 Id at 197-98 (“[T]he execution of a transaction for a discretionary account is, in 
securities, with the requisite scienter, while in control of the investor's account.

\section{SOPHISTICATION AND SUITABILITY ClaIMS}

\section{A. Whom the Federal Securities Laws Protect}

Courts have not always agreed about whom the federal securities laws protect. ${ }^{87}$ The debate over the scope of the federal securities laws stems in part from a conflict between the legislative intent and the plain language of the Securities Act of 1933 and the Securities Exchange Act of $19344^{88}$ In creating a federal law of securities, Congress was primarily concerned with brokers preying on unsophisticated, individual investors who might be adversely affected by misrepresentations, manipulative schemes, and inadequate disclosure. ${ }^{89}$ However, the language of the securities laws only infrequently differentiates between sophisticated and unsophisticated investors. ${ }^{90}$ The apparent tension between legislative intent and statutory language is reflected in Justice Stevens's dissent in Landreth Timber Co. $v$ Landreth, a case in which the Supreme Court held that common stock is a security even when it is merely used to effect the sale of a business. ${ }^{91}$ Justice Stevens argued that Congress's overwhelming concern over protecting unsophisticated investors must provide the basis for limits on the scope of the Securities Acts and suggested that the sophistication of a business purchaser could provide adequate protection from fraud. ${ }^{92}$ Stevens' view is contrasted by the strict textualist approach of the district court in Newman $v$ Shearson,

function, a form of recommendation. ... As such, it creates the same duties."). See also Mauriber $v$ Shearson/American Express, Inc., 567 F Supp 1231, 1235-38 (S D NY 1983) (stating that an elderly retiree could sustain an unsuitability claim against broker who used discretionary account to invest in high risk, speculative securities).

${ }^{57}$ Compare Hirsch $v$ du Pont, 553 F2d 750, 763 (2d Cir 1977) ("The securities laws were not enacted to protect sophisticated businessmen from their own errors of judgment."), with Lehigh Valley Trust Co. $v$ Central National Bank of Jacksonville, 409 F2d 989, 992 (5th $\mathrm{Cir}$ 1969) ("Neither Congress nor the Securities and Exchange Commission has indicated that the unsophisticated and the unwary are the only wards of Rule 10b5.").

${ }^{88}$ See C. Edward Fletcher, III, Sophisticated Investors Under the Federal Securities Laws, 1988 Duke L J 1081, 1133-37 (discussing the conflict between the legislative history of the Securities Acts and their textual provisions).

89 Id.

To The text of Rule 10b-5 is a typical example of language that fails to differentiate between types of investors. See note 11 .

${ }^{91} 471$ US 681, 697 (1985).

\$2 Id at 698 (Stevens dissenting) ("I believe that Congress wanted to protect investors ... who are not in a position to protect themselves from fraud."). 
Hammill \& Co.: "The federal securities laws do not distinguish between sophisticated and unsophisticated investors, and the protection afforded by [the] antifraud and registration provisions are designed for all investors, whether sophisticated or unsophisticated." ${ }^{93}$

The tension between the historical and textual readings of the securities laws is reflected in suitability cases, where courts, as one commentator has noted, have not presented "any coherent theory to justify [the] different treatment of sophisticated and unsophisticated customers." ${ }^{94}$ Suitability claims bring into sharp relief the debate over whom the federal securities laws are designed to protect, precisely because suitability is the type of fraud from which sophisticated investors need the least protection. Suitability claims concern the assessment of risk. Sophisticated investors, who are familiar with financial markets, are in a stronger position than unsophisticated investors to assess the risk of their investments despite the misrepresentations, omissions, or fraudulent practices of their brokers. Courts addressing suitability claims have only infrequently grounded their discussions of investor sophistication on statements about the purposes of federal securities law. ${ }^{95}$ Nonetheless, the trend in suitability cases has been against sophisticated investors. ${ }^{96}$

\section{B. Sophistication and Causation in Suitability Claims}

In a private action under Rule $10 \mathrm{~b}-5$, the investor must allege that the broker caused the investor's losses. Sophisticated investors have had difficulty meeting this requirement. In suitability claims based on omission, causation may be satisfied by the presence of a duty to disclose within a fiduciary relationship. ${ }^{97}$ In suitability claims based on misrepresentation, causation may be demonstrated through the element of justifiable reliance. ${ }^{98}$ With respect to both omission and misrepresentation

93383 F Supp 265, 268 (W D Tex 1974).

94 Fletcher, 1988 Duke L J at 1109 (cited in note 88).

9s But see Bull v Chandler, [1991-92 Transfer Binder] Fed Sec L Rep (CCH) II 96,567 at 92,622 (N D Cal 1992) ("The federal securities laws are not an insurance policy for investors who trust their financial well-being to salespersons who have no legal duty to look out for their best interests."). See note 15 .

96 See Fletcher, 1988 Duke L J at 1108-09 (cited in note 88) (noting that more sophisticated investors are less likely to win suitability claims).

${ }^{97}$ See text accompanying notes 55-57.

${ }^{98}$ See Affiliated Ute Citizens, 406 US at 153-54. See also text accompanying notes $62-$ 63. 
claims, investor sophistication undermines the basis for causation. In suitability claims based on fraudulent practice, the broker's control over the account may establish causation. ${ }^{99}$ Unlike in misrepresentation and omission claims, however, sophistication does not necessarily undermine causation in this context. Suitability claims based on fraudulent practice may be open to sophisticated investors who truly relinquish control of their accounts.

1. Sophisticated investors and the presence of a fiduciary relationship.

In the context of many fraud claims, courts have required brokers to fulfill their fiduciary duties even in dealing with sophisticated investors. In Hanly $v S E C$, for example, five brokers made affirmative misrepresentations to customers concerning stock purchases. ${ }^{100}$ In affirming the SEC's disciplinary action, the Second Circuit stated that "a salesman cannot deliberately ignore that which he has a duty to know and recklessly state facts about matters of which he is ignorant. . . . The fact that his customers may be sophisticated and knowledgeable does not warrant a less stringent standard." ${ }^{\text {101 }}$ Similarly, in Lehigh Valley Trust Co. $v$ Central Natl Bank of Jacksonville, the Fifth Circuit was not persuaded by the "sophisticated purchaser" defense offered by a bank that failed to disclose, and misstated, material facts in the sale of a loan participation. ${ }^{102}$ The court stated that "[t]he commercial morality espoused by the Federal Securities Acts . . . requires full and truthful disclosure of material information, even in transactions between sophisticated financial institutions." "103

This view, however, has not gained wide acceptance in suitability cases, where courts have instead found that an investor's sophistication defeats the presence of a fiduciary duty unless the broker exercises control over the account. ${ }^{104}$ In Bull $v$ Chandler, the investor was an engineer who signed forms attesting to his

\footnotetext{
99 See text accompanying notes 74-78.

100415 F2d 589, 592 (2d Cir 1969).

101 Id at 596.

102409 F2d 989, 990 (5th Cir 1969).

103 Id at 994.
}

104 See, for example, City of San Jose v Paine, Webber, Jackson \& Curtis, Inc., 1991 US Dist LEXIS $8318, * 4-5(\mathrm{~N} \mathrm{D} \mathrm{Cal)} \mathrm{(order} \mathrm{memo)} \mathrm{(finding} \mathrm{that} \mathrm{all} \mathrm{transactions} \mathrm{involving}$ city were conducted at arms length). 
sophistication and suitability as an investor. ${ }^{105}$ In evaluating whether the investor justifiably relied on the broker's alleged misrepresentation, the court stated that "[t]here was no fiduciary relationship between plaintiff and [the broker]. [The broker] had no discretion to trade on his account; rather plaintiff approved all transactions." 106

As Bull demonstrates, courts evaluating suitability claims have been unsympathetic to allegations that brokers were engaged in anything more than arm's-length transactions with sophisticated investors. Arguably, this is consistent with the purpose of federal securities law $^{107}$ and accurately reflects the nature of financial transactions between brokers and sophisticated investors. The unwillingness of courts to recognize a fiduciary duty in this context has implications for all three types of suitability claims: the absence of a fiduciary relationship eviscerates suitability claims based on omission by removing the duty to disclose, weakens suitability claims based on misrepresentation by undermining justifiable reliance, ${ }^{108}$ and defeats suitability claims based on fraudulent practice by precluding a finding of account control.

2. Sophisticated investors and justifiable reliance.

In the aftermath of the Supreme Court's decision in Ernst \& Ernst establishing scienter as a requirement in Rule 10b-5 cases, ${ }^{109}$ federal judges reevaluated the notion of justifiable reliance in the context of sophisticated investors. Previously, some courts had required that a sophisticated investor demonstrate due diligence in order to establish that the investor justifiably relied on the fraudulent actions in question. ${ }^{110} \mathrm{~A}$ series of cases

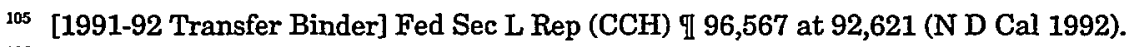

106 Id.

107 See text accompanying notes 87-93.

${ }^{208}$ One commentator has suggested that a fiduciary relationship could be found where a sophisticated investor relies on the suitability advice of his more knowledgeable broker. The investors could then use this relationship to establish justifiable reliance. Root, 1991 Colum Bus L Rev at 343-44 (cited in note 16). Although this scenario is conceivable, to date, fiduciary relationships between sophisticated investors and brokers in suitability cases have only been established through actual broker control over the trading account. See text accompanying note 104 .

${ }^{109} 425$ US at 193. See text accompanying notes 50-51.

110 See, for example, Hirsch v du Pont, 553 F2d 750, 763 (2d Cir 1977) ("The securities laws were not enacted to protect sophisticated businessmen from their own errors of judgment.... We believe that the due diligence of the [defendants] in this case fell far short of the mark."). 
following Ernst \& Ernst, however, attempted to bring some unity to the standard imposed on all investors. In Dupuy $v$ Dupuy, a Rule $10 \mathrm{~b}-5$ case brought by a sophisticated investor, the Fifth Circuit reasoned that "[b]oth tort law and federal securities policy support imposing on the plaintiff only a standard of care not exceeding that imposed on the defendant." Mallis $v$ Bankers Trust Co., subsequently agreed, holding "that in the light of Ernst \& Ernst a plaintiff's burden is simply to negate recklessness when the defendant puts that in issue, not to establish due care."112 A number of suitability cases have used this standard, or a similar one, to evaluate whether investors, sophisticated and unsophisticated, justifiably relied on the misrepresentations of a broker.

For example, in Brown v E.F. Hutton Group, Inc., a group of investors, despite having the relevant offering materials, claimed to have relied on the oral misrepresentations of their broker in investing in a limited partnership to acquire oil and gas properties. ${ }^{113}$ Accepting the investors as unsophisticated for the purposes of its decision, the Second Circuit compiled a list of relevant factors that courts have used to determine whether or not an investor acted recklessly for purposes of establishing Rule 10b-5 liability:

(1) The sophistication and expertise of the plaintiff in financial and securities matters; (2) the existence of long-standing business or personal relationships; (3) access to the relevant information; (4) the existence of a fiduciary relationship; (5) concealment of the fraud; (6) the opportunity to detect the fraud; (7) whether the plaintiff initiated the stock transaction or sought to expedite the transaction; and (8) the generality or specificity of the misrepresentations. ${ }^{114}$

Although the court argued that all of the factors must be considered and balanced, it ultimately based its decision to affirm a grant of summary judgment in favor of the broker on access to relevant information, concluding that the offering materials adequately explained the risks involved. ${ }^{115}$ 
Other cases have directly focused on sophistication to the virtual exclusion of other factors. In Platsis v E.F. Hutton \& Co., the investor, a lawyer, claimed that the broker had made oral misrepresentations concerning the suitability of investing in oil and gas limited partnerships. ${ }^{116}$ The court held that "[i]n view of plaintiff's sophistication, education, and admission that he read the [offering memorandum] 'cover to cover', the court is not persuaded that he in fact relied on oral statements or, in any event, that such reliance, if any, was justified."117 Likewise, in Xaphes v Merrill Lynch, Pierce, Fenner \& Smith, Inc., the investor, a lawyer and former city treasurer, was deemed to be a sophisticated investor in constant contact with his broker. ${ }^{118} \mathrm{Be}$ cause the investor "was fully able to understand the risks and make the choices that he did make," the court rejected his suitability claim. ${ }^{119}$ As these cases demonstrate, sophisticated investors have fared poorly in attempting to establish suitability claims based on misrepresentation. Courts have recognized that a misrepresentation of risk to a sophisticated investor should not be considered fraud when the investor is capable of seeing through the misrepresentation.

\section{Sophisticated investors and control.}

Plaintiffs generally establish control "either through evidence that the account was discretionary or that the 'customer is unable to evaluate [the broker's] recommendations and to exercise an independent judgment."'120 In Leib $v$ Merrill Lynch, Pierce, Fenner \& Smith, Inc., a sophisticated investor claimed that his broker had engaged in churning. ${ }^{121}$ The court discussed a number of factors, mirroring those suggested by the Brown court for use in evaluating justifiable reliance, that might lead to the conclusion that the broker had assumed constructive control over the account. ${ }^{122}$ On the basis of Leib's sophistication and constant monitoring of his account, the court concluded that Leib's broker

116642 F Supp 1277, 1288 (W D Mich 1986), aff'd, 829 F2d 13, 13 (6th Cir 1987).

11 Id at 1299.

11632 F Supp 471, 481-82 (D Me 1986).

119 Id at 482.

120 City of San Jose $v$ Paine, Webber, Jackson \& Curtis Inc., 1991 US Dist LEXIS $8318, * 1,6$ (N D Cal) (order memo), quoting Follansbee, 681 F2d at 677. See Section II.B.1.

122461 F Supp 951, 952 (E D Mich 1978), aff'd, 647 F2d 165 (6th Cir 1981).

122 Id at 954-55. 
did not control the account. ${ }^{123}$ In another churning case, Tiernan $v$ Blyth, Eastman, Dillon \& Co. ${ }^{124}$ the First Circuit suggested that a court must consider evidence of the investor's sophistication, in addition to evidence that the investor routinely followed his broker's recommendations, in determining control. "To hold otherwise," the Tiernan court noted, "would prevent imputing control to the highly sophisticated investor who actively monitors his account but typically does not disagree with his broker's recommendations." 125

Another possibility, however, is a sophisticated investor who relinquishes all decisions to his broker. Although no cases have explored this scenario, ${ }^{126}$ a sophisticated investor who establishes that he had conservative objectives and did not participate in the investment decision-making process ought to be able to state a viable suitability claim based on fraudulent conduct. ${ }^{127}$ Indeed, this is exactly the sort of contention that public entities are likely to pursue in the wake of losses from derivatives trading.

\section{PUblic ENTIties and SutTability Clatms}

Only a handful of suitability claims brought by public entities have generated judicial opinions. In Utah State University $v$ Bear, Stearns \& Co., the university brought actions against various securities brokers alleging that its investments were unsuitable and ultra vires. ${ }^{128}$ The Tenth Circuit dismissed the suitability claim for failure to allege scienter. ${ }^{129}$ In Village of Arlington Heights $v$ Poder, the court demonstrated how suitability and unauthorized trading can become intertwined. ${ }^{130}$ The village and its pension funds sued Drexel Burnham Lambert Government Securities, Inc. over alleged unauthorized trading by the

${ }^{123}$ Id at 956-57.

124719 F2d 1 (1st Cir 1983).

125 Id at 3.

126 The Tiernan court did, however, note the possibility. Id at 3-4 n 2.

127 At least one case has come close. In Frota v Prudential-Bache Securities, Inc., [1987 Transfer Binder] Fed Sec L Rep (CCH) II 93,253 at 96,217 (S D NY), the investors established an account worth almost $\$ 2.5$ million dollars and gave discretionary control to the broker. Although the investors' status was not discussed by the court, an account of that magnitude suggests a level of sophistication. The investors, however, were rarely in the country and only irregularly received statements from the broker. Thus, the court concluded that the investors had established a claim for suitability based on omission. Id at 96,217-18. See also City of San Jose, 1991 US Dist LEXIS 8318 at $* 5-8$ (suggesting in order memo that city may have to establish lack of control to succeed in suitability claim).

128549 F2d 164, 166 (10th Cir 1977).

129 Id at 169.

130712 F Supp 680, 681 (N D Il 1989). 
village treasurer and misrepresentations by the broker concerning the suitability of the trades in question. The court held that, for purposes of stating a valid claim under Rule $10 \mathrm{~b}-5$, the broker's failure to inform the pension funds of the treasurer's unauthorized transactions was a material omission and that the broker may have had a fiduciary duty to inform the funds of the treasurer's actions. ${ }^{131}$ The suitability claim itself, however, was dismissed for failing to specify the nature of the alleged misrepresentations. ${ }^{132}$

In contrast, in Minneapolis Employees Retirement Fund $v$ Allison-Williams Co., a public pension fund brought a suitability claim against its broker under Minn Stat $\S 80 \mathrm{~A} .01$, which is patterned after Rule 10b-5. ${ }^{133}$ Analyzing the claim using the elements established for fraudulent practice suitability claims by the Tenth Circuit in O'Connor, the Minnesota Supreme Court held that the pension funds had failed to satisfy any of the three necessary elements: the pension fund's investment objective-increased returns-was satisfied by investing in high-yield bonds; there was no evidence that the broker had acted recklessly in recommending the purchase of bonds; and the broker had no authority to enter into transactions on behalf of the pension fund. ${ }^{134}$

The only other case involving claims that closely resemble current claims by public entities, City of San Jose $v$ Paine, Webber, Jackson \& Curtis, Inc. ${ }^{135}$ has no precedential value, because the district court did not publish an opinion and the parties dismissed their appeal pursuant to a later settlement agreement. $^{136}$ Nonetheless, the outcome may have encouraged the recent spate of suitability claims by public entities. San Jose brought suitability, churning, and ultra vires claims against its broker over a series of high-risk securities transactions. A jury found in favor of the city on its suitability claim and on its claim for damages associated with ultra vires transactions. ${ }^{137}$ The brokers appealed the decision, but dropped the appeal as part of the

131 Id at 683 .

${ }^{132}$ Id at 687 .

133519 NW2d 176, 179 (Minn 1994).

134 Id at 180-81. For a discussion of these necessary elements see text accompanying note 73.

1351991 US Dist LEXIS 8318 (N D Cal) (order memo).

${ }^{136}$ See Mark Cursi, San Jose, Brokers Settle Suit Over Losses in Bond Market, The Recorder 4 (Dec 31, 1991) (available in LEXIS) (discussing settlement terms). See also text accompanying note 9 .

${ }^{137}$ San Jose, Calif., Gets \$18.5 Million Award, Wall St J at C13 (cited in note 9). 
settlement. ${ }^{138}$ Although the appellate court did not write an opinion, it did provide the parties with an order memorandum laying out the issue of suitability for oral argument. ${ }^{139}$ In the memorandum, the court noted that the city had not established whether its suitability claim was based on omission or fraudulent practice. ${ }^{140}$ However, the court had already determined that:

[T]he defendants were acting as self-interested dealers engaging in arm['s]-length transactions. . . . There is simply no authority for the City's contention that even if the dealers were acting solely as principals in their trades with the City, rather than as agents or brokers, they still owed a fiduciary duty. ${ }^{141}$

Because the brokers did not owe the city a fiduciary duty, the city could not prevail on an omission theory. The court then framed the issue of whether control is an essential element for a suitability claim brought under a fraudulent practice theory and left that question open for oral argument. ${ }^{142}$

Taken together, the relevant cases brought by public entities and sophisticated investors demonstrate that any window of opportunity through which a public entity can pursue a suitability claim based on derivatives losses is small. The facts underlying a claim will ultimately be determinative. Nonetheless, by assuming that the public entity is capable of proving that the disputed investments were unsuitable, one can discern a general pattern.

A suitability claim based on a broker's failure to inform the public entity about the risks of derivatives should fail, unless the public entity is able to establish that the relationship between the broker and the public entity was a fiduciary one. However, such a relationship is uncharacteristic of the normal arm's-length transactions found in the derivatives market, and, as evidenced by the appellate court's order memorandum in City of San Jose, the absence of a fiduciary relationship poses an insurmountable barrier to a successful omission claim. ${ }^{143}$ A suitability claim alleging that the broker misrepresented the risks of derivatives should likewise fail unless the public entity can establish justifi-

${ }^{138}$ Cursi, San Jose, Brokers Settle, The Recorder at 4 (cited in note 136).

139 City of San Jose, 1991 US Dist LEXIS 8318, *1-8.

140 Id $* 1-2$.

141 Id *4-5, quoting Order filed May 28, 1990 at 3.

${ }^{162}$ City of San Jose, 1991 US Dist LEXIS 8318, *5-8.

143 Id *3-4. 
able reliance. Establishing justifiable reliance, however, would be a significant barrier in any case, given the outcome of previous misrepresentation suitability claims brought by sophisticated investors.

Given the significant obstacles to successful suitability claims based on omission and misrepresentation, public entities are most likely to seek recovery of their derivatives losses by bringing suitability claims based on fraudulent conduct. To support such a claim, the public entity does not need to establish a fiduciary duty or justifiable reliance. Instead, it can try to establish the element of control by arguing that the complexity of derivatives, and its own comparative lack of sophistication, allowed the broker to establish constructive control of the trading account.

Any type of suitability claim over derivatives brought by a public entity will involve three major determinations: the sophistication of the public entity; whether ultra vires claims can be used to support the public entity's contention that derivatives were unsuitable investments; and, as discussed in Section V, the investment strategy of the public entity and the burden of risk. Courts should use these determinations as a basis for judicial limitation of the suitability doctrine in the context of claims brought by public entities.

\section{A. The Sophistication of Public Entities}

Courts have long presumed that institutional investors, including corporations and public entities, are sophisticated for purposes of the federal securities laws. ${ }^{144}$ Although courts have rarely had opportunities to consider the sophistication of public entities in the context of securities fraud cases, limited precedent indicates that courts will be inclined to view public entities as at least prima facie sophisticated. In Ohio v Peterson, Lowry, Rall, Barber \& Ross, the state sued a law firm in connection with the sale and purchase of promissory notes. ${ }^{145}$ In assessing whether Ohio's due diligence had been sufficient to overcome the preclusive effect of the expired statute of limitations, the court considered the state's sophistication. The court concluded that "the

14 See Robert Clark, Corporate Law $\S 17.3$ at 730 (Little, Brown 1986) ("Institutional investors are usually sophisticated and powerful enough to demand and get the information they need before committing their money. The legal system does not have to protect them with a superimposed mandatory disclosure system.").

145472 F Supp 402, 404 (D Colo 1979). 
state of Ohio is much more than a casual dabbler in the securities market. The size of the claim alone implies that a degree of care and diligence should be employed in its pursuit." ${ }^{216}$ Similarly in Minneapolis Employees Retirement Fund, the state court found that the pension fund was sophisticated enough to invest in high-yield speculative bonds, noting that the purchase of these bonds "by an institutional investor such as a pension fund is a common transaction." 147

In addition, a recent decision by the Supreme Court of Appeals of West Virginia asserts that courts should consider public entities to be sophisticated investors. In West Virginia $v$ Morgan Stanley \& Co., the broker faced charges of speculation, fraud, and constructive fraud under West Virginia state law stemming from derivative transactions with the West Virginia Consolidated Fund, an investment pool made up of public monies. ${ }^{148}$ The court stated:

Notwithstanding that Morgan Stanley sedulously cultivated good customer relations with the State of West Virginia, Morgan Stanley was nonetheless a principal in the transactions at stake, not a broker, and Morgan had the right to trade with the State without undertaking the obligation to insure the State against its elected officers' lack of wisdom. "Sophistication", as that term is used in the investment law, should never be confused with intelligence, prudence or good luck. ${ }^{149}$

It would be hard to find fraud, the court concluded, when the officials at the state treasury were sophisticated investors subject to legislative oversight. To say that Morgan Stanley could not have reasonably relied on representations from the appropriate investment officers was "tantamount to confessing that West Virginia officials must at all times be treated as either children or incompetents. We are unwilling to accede to this proposition. $" 150$

Even if courts generally conclude that public entities are sophisticated, the nature of that sophistication still may come into dispute. Courts will undoubtedly be asked to decide whether 
sophistication should be measured by the institutional capacity of the public entity or the individual capacities of the public entity's decision makers. In Memphis Housing Auth. $v$ Paine, Webber, Jackson \& Curtis, Inc., for example, a city housing authority brought a churning claim against its broker. ${ }^{151}$ Blurring the line between suitability and churning, the city argued that the broker's failure to warn the city official in charge of the account about the unsuitability of the investments effectively eliminated the city's control over the account. ${ }^{152}$ In denying the broker's motion for summary judgment, the court recognized "the fact that [the city official] rejected some of defendant's investment recommendations does not negate the possibility that [the city official] generally followed defendant's recommendations or that his appearance of independence was a facade used to mask his embarrassment at being inexperienced." ${ }^{\prime 153}$ This case illustrates the tendency of some courts to equate the sophistication of the public entity with the sophistication of individual officials in determining the causation/reliance element of suitability claims. Even in West Virginia $v$ Morgan Stanley, where the court held that the state officials in question were sophisticated investors, the opinion conceded that a jury might take the fact "that Morgan Stanley did know that the people who were running the Investment Division of the West Virginia State Treasurer's office were not potential nominees for the Nobel Prize in Economics" into consideration in determining "Morgan Stanley's overall culpability."154

Given the unclear role of the sophistication of the public officials involved in the disputed trades, counsel on both sides of a Rule 10b-5 suitability claim will naturally attempt to frame the issue of sophistication in a light favorable to their clients. For example, in City of San Jose, the parties characterized the sophistication of the city in markedly different terms. In their appellate brief, the brokers argued that "[i]n light of the City officials' active control over each investment decision, the experience of its investment officers, and their use of multiple sources of information, plaintiff failed to establish that defendants proximately caused plaintiff's investment decisions." ${ }^{155}$ In contrast,

151639 F Supp 108, 110 (W D Tenn 1986).

152 Id at 114-15.

153 Id at $115 \mathrm{n} 8$.

$154459 \mathrm{SE2d}$ at 919.

${ }^{155}$ Defendants E.F. Hutton \& Company, Inc.'s and PaineWebber, Inc.'s Memorandum of Points and Authorities In Support of Motion For a Judgment Notwithstanding the Verdict, Or Alternatively, A New Trial or Remittitur 34, City of San Jose v Paine, Webber, 
the city contended that its officials "were not able to fully understand the advice and information being given to them by PaineWebber and Hutton, and thus relied upon the recommendations being made."156 The city also focused on the lack of sophistication of the brokers' alleged primary contact person, noting that the official "had no formal training in investing and, for many years prior to assuming responsibilities for investing, his responsibilities were essentially clerical such as the collection of sewer tax revenues."157

The possibility of "piercing the veil" of prima facie sophistication to get at the sophistication of the individual decision makers is probably unique to public entities. Large corporations, for example, would have difficulty claiming that their officials are not sophisticated investment professionals. ${ }^{158}$ Furthermore, assessing sophistication based on the competence of their agents might give public entities a perverse incentive to avoid seeking professional investment advice. Investing in high-risk securities would become a win-win proposition. Either the public entity's investments are successful, and it keeps the gains, or the public entity brings a suitability claim to recover any losses from its brokers, using the incompetence of its officials to rebut the presumption of sophistication. ${ }^{159}$

The topic of public-entity sophistication has been extensively debated in the aftermath of recent losses. In a 1991 congressional hearing, the Attorney General for the State of West Virginia argued: "A State is not necessarily a sophisticated investor. In fact it is safe to assume that most public entities cannot afford to hire the best-qualified securities professionals, and as a result, they probably rely more on the dealers for investment advice. ${ }^{1160}$ Four years later, Marc Lackritz, the President of the

Jackson \& Curtis, Inc., 1991 US Dist LEXIS 8318 (N D Cal) (on file with U Chi L Rev).

156 Plaintiff's Memorandum in Opposition to Dealers' Motion for JNOV, or Alternatively, New Trial or Remittitur in City of San Jose $v$ Paine, Webber, Jackson \& Curtis, Inc. 13, City of San Jose, 1991 US Dist LEXIS 8318 (on file with U Chi L Rev).

157 Id at 14.

158 Recently, the Commercial Court of the English High Court of Justice rejected this theory in a suit over derivative losses between Bankers Trust and Dharmala, an Indonesian financial services firm. Dominic Benciverga, Blueprint for Dealers: U.K. Derivatives Ruling Guide for U.S. Litigation, NY L J 5 (Dec 4, 1995) (available in LEXIS). The court held that Bankers Trust did not owe Dharmala a duty of care to explain the risks of its derivative transactions. V.B.

${ }^{159}$ For further discussion, including the incentives created for brokers, see Section

160 Hearings on Government Securities Reform before the House Subcommittee on Telecommunications and Finance, 102d Cong, 1st Sess 11 (1991) (statement of Mario J. 
Securities Industry Association, told a Senate panel that "[c]ounty treasurers are free to obtain financial advisors," and dealers who sell securities to public entities are not necessarily obligated to serve as advisors. ${ }^{161}$

It is not unreasonable for brokers to assume that public entities have the capacity to evaluate their investments. As Professor Markham has recently noted: "[I]nstitutional investors should not be treated as widows and orphans who must be protected from derivative instruments by fiduciary duties." ${ }^{\text {162 }}$ Public entities should not be able to rely on incompetent agents and then demand that their brokers, as other principals, insure their investments. Derivative transactions can be complex, and public entities may not entirely comprehend the nature of the risks involved. Nonetheless, at a more basic level, public entities are clearly sophisticated enough to understand that they are taking risks and that outside financial advice may be necessary.

If courts do not compel public entities to take responsibility for monitoring their own investments by rejecting suitability claims, they will undermine the force of the Supreme Court's holding that there is no "general duty between all participants in market transactions." 163 Fidelity to this principle requires courts to follow established precedent and hold that a public entity is sophisticated based on its institutional capacity.

\section{B. The Use of Ultra Vires Claims}

Courts have addressed the issue of whether financial transactions between public entities and brokers can be voided because they are outside the authority of the public entity - that is, because they are ultra vires-only infrequently. A full discussion of unauthorized trading and ultra vires cases is outside the scope of this Comment. ${ }^{164}$ Ultra vires claims, however, have also been

\footnotetext{
Palumbo, Attorney General of West Virginia).

161 Witnesses Tell Senate Panel No Derivatives Legislation Necessary, 27 Sec Reg \& L Rep (BNA) 75 (1995).

162 Jerry W. Markham, Protecting the Institutional Investor: Jungle Predator or Shorn Lamb?, 12 Yale J Reg 345, 376 (1995).

163 Dirks, 463 US at 654-55, quoting Chiarella, 445 US at 232-33.

164 Note that ultra vires claims may be enormously important in aiding public entities in the recovery of derivative losses. In Hazell $v$ Hammersmith and Fulham London Borough Council, the British House of Lords held that over 592 swap and other derivative transactions entered into by a borough council were invalid because the borough had no authority to enter into swap transactions. [1992] 2 App Cas 1, 37 (1991) (appeal taken from CA). However, since Hazell was decided, many U.S. states have enacted laws expressly permitting government entities to engage in swaps for the purpose of hedging. See
} 
used to support the investor's burden of proof concerning its investment objectives. Public entities have claimed that trading was unsuitable because it was outside of the investor's statutory authority. Three years after the disputed investments in Utah State University were made, the Supreme Court of Utah held that the university did not have the power to purchase common stock with its public funds. ${ }^{165}$ The university suggested that this decision supported its suitability claim. The Tenth Circuit disagreed, stating:

The argument that the brokers are liable because they should have known that the stock purchases by USU were illegal under Utah law does not impress us. USU seeks to take advantage of its own wrongful acts. It would retain the profits which it has made and recover from the brokers the losses which it has sustained. An ultra vires act of an institutional customer may not be converted into a wrongful act of a broker. ${ }^{166}$

Although the court's holding in Utah State University seems to be strong precedent against using ultra vires claims to support suitability claims, future courts could limit that holding by applying it only in cases where the determination of illegality postdates the investments. In Minneapolis Employees Retirement Fund, however, the state court also held that the public entity's investment objectives, presented to the broker by the public entity, were all that the broker needed to consider in determining suitability. ${ }^{167}$ Moreover, the current NASD and NYSE rules ${ }^{168} \mathrm{em}-$ phasize disclosure by the investor rather than investigation by the broker. Courts should follow these general trends in the case law and regulatory schemes in evaluating the use of ultra vires claims to support determinations of suitability and not require brokers to investigate the legal authority of public entity investors.

Laurence D. Dobosh and Florence D. Nolan, Certain Issues Relating to Enforceability of OTC Derivatives, 873 PLI/Corp 57, 65 (1994).

165549 F2d at 166.

166 Id at 168.

167519 NW2d at 180.

${ }^{168}$ See notes $36-37$ for the text of these rules. 


\section{DERIVATIVES AND THE DETERMINATION OF SUTTABILITY}

A. Investment Strategy

In his seminal article on suitability in 1965, Professor Mundheim discussed why securities professionals were troubled by the suitability doctrine:

A case which seems particularly to frighten the securities industry is the one in which the "greedy old lady" who has lost money speculating in the market comes into court posing as the "sweet trusting widow" who has put her life savings into what is now worthless stock and asks a jury to give her relief against her faithless (and wealthy) broker. ${ }^{169}$

The substitution of "city" for "lady" and "widow" in Professor Mundheim's example accurately describes the case that seems to frighten the securities industry today. Public entities have turned to the derivatives market not only to hedge against risk, but also to obtain higher returns on their investments. Orange County's investment fund, for example, averaged annual returns of 10 percent over the last fifteen years. ${ }^{170}$ These returns resulted from an investment strategy that openly relied on using leverage and structured interest rate securities and was predicated on interest rates remaining low. ${ }^{171}$ The President of Odessa College, testifying before the House Committee on Banking, Finance and Urban Affairs, stated that his institution had been forced to seek higher rates of return on its investments because of budget difficulties. ${ }^{172}$ Between 1990 and 1993, "the college's investment in [collateralized mortgage obligations] produced a good rate of return and there was no indication of problems with regard to these investments." ${ }^{273}$ However, the rise in interest rates during 1994 rapidly changed the fortunes of both Orange County and Odessa College.

Sudden losses by investors seeking higher returns, but unwilling to acknowledge the incumbent risks of speculating, have not inspired much judicial sympathy. In an early suitability case,

169 Mundheim, 1965 Duke L J at 464 (cited in note 10).

170 Sallie Hofmeister, Many Questions, But Too Late, NY Times D1 (Dec 6, 1994).

171 Derivative Financial Instruments Hearings at 56-57 (Jan 5, 1995) (cited in note 3) (statement of Arthur Levitt) (based on Orange County Treasurer's Reports from the past few years).

${ }_{172}$ Recent Derivative Losses Hearings at 90 (cited in note 34) (statement of Philip Speegle, President of Odessa College) (cited in note 34).

${ }^{173}$ Id at 92. 
the court in Hecht $v$ Harris, Upham \& Co. summarized what has become a prevailing view toward cases brought by sophisticated investors: "[T]he purpose of the Securities Exchange Act is to protect the innocent investor, not one who loses his innocence and then waits to see how his investment turns out before he decides to invoke the provisions of the Act." ${ }^{\text {"174 }}$ By entering into the derivatives market to achieve higher returns, public entities shed their innocence. In many cases, the suitability of derivative investments for public entities has been determined at the legislative level, where statutes governing the investment policies of public entities have been changed to permit derivative investments. ${ }^{175}$ Courts should be skeptical of public entities who, after seeking and receiving higher returns in the derivatives market, come into court claiming that recent losses now indicate that the investments were unsuitable.

Public entities also may point to the high risks associated with individual derivative instruments, as opposed to the risky nature of derivative investments in general, as evidence of unsuitability. Courts should be very careful, however, in assessing a broker's actions on this basis. Portfolio theory argues that examining the risks of an individual security tells the observer very little about the overall risk of an investment portfolio. ${ }^{176}$ In other words, the marginal impact of a derivative instrument on the risk of the portfolio cannot be determined by looking at the instrument in isolation; rather, one must measure its contribution to the overall risk level of the portfolio. ${ }^{177}$ That contribution de-

134430 F2d 1202, 1207 (9th Cir 1970), quoting Royal Air Properties, Inc. v Smith, 312 F2d 210, 213-14 (9th Cir 1962). Interestingly, the plaintiff in the Hecht case was, in fact, an elderly widow. Hecht, 430 F2d at 1206.

175 In California, for example, state law allowed public entities to engage in both swap agreements (for hedging purposes) and reverse repurchase agreements (for liquidity purchases). Following the well publicized losses suffered by public entities trading in derivatives, however, some states may move in the opposite direction. See, for example, Ohio Official Proposing a Ban on Derivatives, St. Louis Post-Dispatch 11C (Feb 14, 1995).

${ }^{176}$ See Richard A. Brealey and Stewart C. Myers, Principles of Corporate Finance $\S$ 8.2 at 163 (McGraw-Hill 4th ed 1991).

177 This same point also informs the question of appropriate damage assessment. In other words, should losses from particular derivative instruments be looked at in isolation? Orange County, for example, had a great deal of success with its investment policy prior to 1994. See text accompanying note 170. Should the gains from these unsuitable trades be used to offset any losses from unsuitable trades in assessing damages? The West Virginia Supreme Court of Appeals, for example, solved this problem by holding that if "the jury concludes that the fiduciary and/or any aider and abetter is entirely innocent of intentional wrongdoing, then the jury may offset losses that arose from speculation with gains that arose as a direct result of the same type of speculation." West Virginio $v$ Morgan Stanley, 459 SE2d at 920. The West Virginia Supreme Court would seem to be on 
pends on the derivative's sensitivity to changes in the value of the portfolio. Even conservative portfolios may contain individually risky investments.

Portfolio theory is very influential in modern financial management and can have a significant impact on a suitability claim. ${ }^{178}$ The complexity of applying portfolio theory to establish a certain combination of risk and expected return levels may bolster a public entity's argument that it was incapable of understanding a recommended investment strategy. On the other hand, portfolio theory may also make it possible for a broker to demonstrate that individually risky derivative transactions were suitable given the contents of the public entity's entire portfolio. Courts should take portfolio theory into consideration before coming to any conclusions concerning the suitability of disputed investments. In summary, investment strategy can have a significant impact on claims involving derivatives by undermining the idea that losses and unsuitability are easily equated.

\section{B. Burden of Risk}

Applying the suitability doctrine to public entities will shift the burden of risk from the investor to the broker. A public entity would be in a no-lose situation. It could speculate at will, and then keep its gains while recovering its losses in court. Public officials would be encouraged to take greater risks. Brokers, on the other hand, might be disinclined to enter into transactions with public entities, denying some public entities access to valuable financial instruments. ${ }^{179}$ Moreover, such protection would be at odds with the principle that the federal securities laws protect the average investor from the risk of fraud, not from the risk of the market. As the Ninth Circuit stated in Vucinich, it is not fraud "simply because a person is led to make investments

the right track in taking a broader view of damages.

${ }_{178}$ See Root, 1991 Colum Bus L Rev at 347-54 (cited in note 16) (discussing the impact of modern portfolio management on suitability, focusing on the need for investors of all types to make their investment objectives clear).

179 Following Orange County's bankruptcy, California legislators were reportedly considering not only prohibiting speculative borrowing and limiting the use of derivatives in public portfolios, but also expanding the state's local government investment code to include the presumptive conclusion that all public entities are unsophisticated investors. This proposal belies the saying "wishing does not make it so," and its acceptance would cause brokers to raise commissions on transactions involving public entities or to simply drop out of the market. See Sarah Lubman, California Senate Considers New Rules for Investments by Local Governments, Wall St J B5A (Feb 17, 1995). 
that may have turned out to be unprofitable or unwise."180 To apply the suitability doctrine to transactions between brokers and public entities would virtually make the brokers insurers of the investments.

\section{CONCLUSION}

The courtroom failures of sophisticated investors, including public entities, who have filed suitability claims under Rule 10b-5 do not foreclose the possibility of a successful claim in the future. The key element of such a claim will be the complexity of derivatives. To establish the necessary fiduciary relationship, justifiable reliance, or control demanded as proof of causation by various suitability claims, the public entity will probably argue that the complexity of the derivative transactions established a "dominant-subservient" relationship between the parties. ${ }^{181}$ In the absence of an express fiduciary relationship, however, a public entity is more than adequately protected by regular fraud actions pursuant to Rule 10b-5. A broker's misrepresentation concerning the nature of the investment, as distinct from the suitability of the investment, would remain a cause of action under federal securities law. ${ }^{182}$

The lack of statutory and Supreme Court authority concerning suitability claims has allowed for extensive judicial development of the suitability doctrine. It is conceivable that courts will view public entities, or their agents, as sufficiently unsophisticated to warrant special protection in the derivatives market. Just as courts have developed the suitability law, however, they can also limit its application. In light of the purposes of the federal securities laws, courts should reject the notion that public entities are the modern equivalent of sweet trusting widows.

180803 F2d at 460.

182 Medero, Carlinsky, and Hensley, 8 Insights at 6 (cited in note 18).

182 For example, in late 1994, the SEC took action under Rule 10b-5 against Kenneth J. Schulte. The SEC alleged that as a representative for various brokers, Schulte made material misrepresentations and omitted to state material facts in the offer and sale of mortgage-backed security derivatives to municipalities and school districts in Ohio. See Bruce A. Baird, Linda D. Gienberg, and Michael A. Dawson, Current Legal Theories in Litigation Involving Derivative Contracts, C123 ALI-ABA 291, 309-10 (June 2, 1995). 
